\title{
Integrity triad as doubled edged sword for head-teachers' integrity: a case from Nepal
}

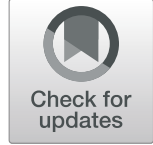

\author{
Bhanu Bhakta Khadka ${ }^{1}$ and Prakash C Bhattarai ${ }^{2^{*}}$ (D)
}

\author{
* Correspondence: prakash@kusoed. \\ edu.np \\ ${ }^{2}$ Department of Development \\ Education, Kathmandu \\ University-School of Education, \\ Lalitpur, Nepal \\ Full list of author information is \\ available at the end of the article
}

\begin{abstract}
Headteachers in the community schools are responsible for academic and administrative activities. They are considered role models for integrity practices. However, the situation is different on some occasions. For instance, political interest plays more important roles than qualifications, training, work experience, etc., in school affairs. In this context, a qualitative study was carried out in the purposefully selected two schools - an urban and a rural - to explore the elements that influence school integrity practices. Data collected from the schools were analyzed and interpreted. The findings show that nepotism, unhealthy party politics, and impunity (integrity triad) influence the school integrity practices in Nepal.
\end{abstract}

Keywords: Integrity triad, Ethnography, Teacher integrity, Integrity in leadership

\section{Introduction}

The term 'integrity' has a wide range of definitions, including those referring to the quality of being morally right and honest. It is derived from the Latin adjective 'integer', which means honesty (Palanski and Yammarino 2007). According to Dunn (2009), integrity means committed loyalty to a strict ethical code or being honest with strong moral principles. As such, integrity has multifaceted meanings and is an abstract concept without a direct litmus test or formula because there is a methodological challenge for integrity study. Moreover, it is difficult and even impracticable to define integrity without relating to culture. Chapfika (2008) argues that teachers having integrity can openly criticize bad things and praise good ideas at personal risks. The author further opines that it requires full courage to challenge bad ideas and act ethically despite the adverse effects or ethical dilemmas. The purpose and essence that an integrity principle holds is a huge task to maintain in the Nepalese context. In such case, headteachers can practice integrity as it helps to communicate lifelong values to the other school stakeholders. Also, Nepali society is divided in party politics, which has somehow diverted people from upholding their integrity. Elaborating on how party politics can switch from its ethical role and responsibility, Bhattarai (2015) argues that teachers' unions are well-wishers of a political party and are more accountable towards politicians on many occasions rather than the school. In this regard, politics reveals

(c) The Author(s). 2021 Open Access This article is licensed under a Creative Commons Attribution 4.0 International License, which permits use, sharing, adaptation, distribution and reproduction in any medium or format, as long as you give appropriate credit to the original author(s) and the source, provide a link to the Creative Commons licence, and indicate if changes were made. The images or other third party material in this article are included in the article's Creative Commons licence, unless indicated otherwise in a credit line to the material. If material is not included in the article's Creative Commons licence and your intended use is not permitted by statutory regulation or exceeds the permitted use, you will need to obtain permission directly from the copyright holder. To view a copy of this licence, visit http://creativecommons.org/licenses/by/4.0/. The Creative Commons Public Domain Dedication waiver (http://creativecommons.org/publicdomain/zero/1.0/) applies to the data made available in this article, unless otherwise stated in a credit line to the data. 
itself to be more individual-centric than integrity or welfare-centered because everything is driven by politics. Some headteachers are also engaged in different businesses to earn for living as they cannot just depend upon regular monthly salaries. For these reasons, they engage in share market, real estate, or any other side businesses; they wish to have multiple sources of income. Given this scenario where the issues are already prevailing and hampering the efficient functioning of schools, the education system demands teachers to keep their professional commitment and morale high (Ministry of Education and Teachers Union of Nepal 2007) without violating the integrity principles. This may be a reason for considering integrity with importance in Nepal.

When history is considered, Nepal had experienced monarchy from 1768 to 2008. This country witnessed the revolution of 1951 that ended the dictatorship of the Rana regime and introduced democracy in the country. The peoples' movement first in 1990 ended the Panchayat system and the movement second in 2006 ended the absolute monarchy. There was a Maoist insurgency from 1996 to 2006 known as the Nepali civil war. On May 28, 2008, the newly elected Constituent Assembly declared Nepal the Federal Democratic Republic, abolishing the 240-year-old monarchy. Nepal today has a President as Head of State and a Prime Minister heading the Government. With the change, people are more aware of the political situations. However, lack of trust among politicians, lack of professional commitment in public service delivery, policy-related corruption, leadership crisis, etc. is prevalent in Nepal. Academia is not considered free from the influence of such abnormalities. Consequently, the integrity of school stakeholders, particularly headteachers, becomes an issue in the sector. With this consideration, a study was carried to explore the elements that influence the integrity practices in school. Before the elements are presented, the notion of integrity and the methods of study have been presented.

\section{Development of the notion of integrity}

In Nepal, National Integrity Policy 2017 has been drafted to promote integrity and governance. This launched a discourse to minimize the ongoing unethical practices and created a debate in mass media alongside. Integrity is understood as a culture imbibing the principles of accountability, competence, and ethics without corruption. Studies of Wagley and Regmi (2015); Mathema and Bista (2006); Commission for Investigation of Abuse of Authority (Commission for Investigation of Abuse of Authority 2015) and National Vigilance Center ([NVC], 2017) reveal that politics, impunity, increased corruption, and favouritism have been the main reasons for the diminishing attraction in public education, making teaching profession neither predictable nor determined in the Nepali context. It is for this reason that despite having government policies for the promotion of integrity, intellectuals always criticise it by pointing out that the talented human capital either emigrates or prefers civil servant job due to the distrust that is associated with the integrity policies believing it to be ineffective.

The report of the Office of Auditor General also mentioned that the Ministry of Education lies at the top four highest ranks with $8.74 \%$ of total unclear advance in 2016 due to financial irregularities, lack of evidence, and audit. Nevertheless, educationists Wagley and Regmi (2015) said that plagiarism, poor academic result, textbook distribution, teacher punctuality, and mismanagement are collectively termed academic crimes 
which are related to integrity. The neglect of the integrity triad, i.e. (nepotism, impunity, and party politics) despite being unacceptable is still prevailing and is affecting the working environment by hampering the integrity principle, which is supposed to guide the headteachers.

Integrity is one of the core values that are supposed to be followed by a Guru (teacher). The Sanskrit word Guru has a significant meaning and indicates a counselor, guide, and knowledge expert. The role of Gurus in Nepali culture is of prime importance. They are academic parents who are held in high regard and valued similarly to biological parents. The most common quotations in Nepali society are Acharya Devo Bhava (teachers are like a god), Guru Brahma, Guru Bishnu, and Guru Devo Maheswor (teachers are visualized as creator, preserver, and destroyer). Students chant the above sentence on Teacher's Day to praise teachers and make them happy every year during Saraswati (Hindu goddess of knowledge) Puja.

In Hindu religious traditions, the most important author Vyasa is credited with the sacred book Veda into four texts and the composition of epic Mahabharata, many puranas, and other works. According to Sullivan (1994), Vyasa stands at the head of a chain of teachers (guru-parampara) as the originator and authenticator of these teachings. Also, Mlecko (1982) considers the Guru as a role model and spiritual; therefore, they have been respected since time immemorial. In this context, the study poses a couple of questions related to headteacher integrity who represents a Guru: Have headteachers lost the essence of being a true Guru? Why do the majority of headteachers choose to engage in party politics? Why has favoritism become a common practice in the appointment of a teacher by the headteacher? What is the reason for challenging existing school norms?

It is not only of teachers but headteachers' integrity matters to all the stakeholders as it plays a paramount role in contributing to ethical leadership, which correlates trust and honesty. Noting the fact that integrity promotion is underscored in the constitution and the responsibility that falls on the shoulders of a headteacher to be an exemplary figure in the educational realm. Therefore, this study can be a milestone to help minimizing educational corruption by underscoring the need to identify, practise and promote integrity principles in the schools. In this context, this paper explores the views of community school headteachers regarding their integrity. Furthermore, it examines the way they make decisions to cultivate integrity in school.

\section{Understanding the global context}

Integrity is the most cited word for lip service or beneficial advice from eastern to western philosophy. Louis and Khalifa (2018) show that metropolitan education in US schools has deteriorated badly over the last two decades. It could not be stopped because of nepotism. Despite having a strict policy in the US, nepotism is still a major issue (Osipian 2020). America Charter schools 'legislation permits the management of public funds wisely by removing bureaucratic interference'. However, literature justifies that educational corruption is the main cause of integrity violations (Ertas 2020), often leading to mismanagement of the school fund. On the brighter side, they have been found to play a crucial role in providing recommendations to offer more courses and conduct research that promotes academic integrity among people in society. 
In Jordan, the study carried out by Amshah (2020) among faculty members of universities shows nepotism as one of the major challenges. It confirms that faculty members are both the cause and remedy of the problems. The researcher recommends providing more courses and conducting research that promotes integrity among people in society and contributes to anti-corruption. The study by Biamba (2012) at eight secondary schools in Cameroon also reveals that culture and political contexts are crucial in understanding what principals do and how they conceptualize their principalship for imbibing integrity principles. Also, Le Billon (2003) argues that violation of integrity is a part of the socio-political issue which will bring conflict among the corrupted agency in the long run and thereby lead to the vanish of the integrity.

Similar issues are well discussed by Nas et al. (1986), who refer to bureaucratic politics being well-plated with a legal matter to produce both positive and negative consequences. In Australia, the experienced headteachers of seven schools having religious affiliation were interviewed, and it was found that ethical dilemmas frequently arose when they had to make a multifaceted decision. From the study of Chapman and Lindner (2016), it can be concluded that corruption in higher education is a worldwide concern and threatens integrity as it is highly influenced by politics.

Bretag (2016) in her book titled 'Handbook of academic integrity' examined contextual factors, breaches of academic integrity from Australia, China, India, Egypt, Indonesia, the USA etc. These issues set discourse on integrity movement, integrity conference, interdisciplinary approaches, international perspectives, academic dishonesty, and honour codes so as to set agenda of academic integrity in the global arena. To achieve moral awareness, moral commitment, moral judgment and moral action, Stephens and Wangaard (2016) developed the Achieving with Integrity (AwI) seminar in the secondary school classrooms. But Nepal lacks such rigorous research; only its necessity was felt by the government in 2017 when the national integrity policy was first drafted. However, it has not been implemented till now.

As Nepal is a signatory to the United Nations Convention against Corruption (UNCAC) and also one of the member countries of UNO, SAARC, BIMSTEC, WTO, NAM, Interpol, etc., this study carries value in both national and global contexts in the present globalized age. Especially in the Nepali context, the word integrity is highly heard of during the time of the election, and is popularly used in the government report, academics, oath ceremony, and social sites but unfortunately not practised in personal life. The integrity of gurus (teachers) matters a lot for parents as the latter want their children to be trusted in the hands of someone who are morally and ethically sound and would demonstrate ethical values in conducting their professional duties.

\section{Diversities and integrity in Nepal}

Nepal is a small beautiful landlocked country in South Asia and is bordered by China and India. It is located in the Himalayas and contains eight of the world's ten highest peaks, including Mount Everest. It has three ecological zones: mountains, hills, and plains. It has rich cultural diversity that comprises 125 castes with unique language, tradition, ethnicity and sociocultural practices. The socio-cultural life of Nepal is very closer to Indian people because $80 \%$ of the population are Hindus. The northern part of Nepal has similar culture and lifestyle with the people of Tibet, China. Nepal is 
among the few countries which were never colonized by any other country. It has always been a sovereign nation, so it never celebrates an independence day. It is a country of the birthplace of Lord Buddha (Founder of Buddhism and the light of Asia). It is the only country in the modern world that does not have a rectangular flag, rather it is triangular.

The history of formal education in Nepal covers about 70 years for the general public and it took its course in line with the democratic political system of the country. The school has become a platform and place of interest for politicians, investors, bureaucrats, educationists, etc. because of their vested interests. These situations are justified by Commission for Investigation of Abuse of Authority (2015), which highlights the instances of cases filed against teachers having fake certificates, teaching licenses, bills of operational costs, unclear advances, etc., and thereby making education one of the most corrupt sector in Nepal. The report further reveals the severe issue of ghost schools, failure of teachers to submit the wealth statement, and tampering of date of birth both in citizenship and academic certificates to delay age for the pension.

It is not like the government does not make any efforts to minimize corruption. Despite the government's effort, some of the crucial issues such as high absenteeism of teachers in the name of deputation leave for a political cause, use of school's properties for private commercial purposes, and misuse of the budget still prevails an issue of discussion in Nepal's education sector (NVC, 2017). This may be a reason why Nepal still needs to work to build integrity, transparency, accountability, and the rule of law (National Planning Commission 2015).

In the meantime, the government has been giving its best to maintain the name and fame of community schools through the cancellation of teaching licenses by the teacher service commission to win the faith of the public and discourage nepotism and politicized decision (Ministry of Education [MOE], 2009). While highlighting the influence of politics, Bhattarai (2015) argues that due to the powerful interference of union politics both headteacher and state are largely helpless and meaningless in academic and administrative work inside the Nepali schools. Given all these backgrounds, limited researches related to integrity and its various elements of schools are conducted. Therefore, this study was carried out to fulfill the research gap in the Nepali context.

\section{Research methodology}

Scotland (2012) has proposed four components of the paradigm: ontology, epistemology, methodology, and methods. Among them, the ontological position of this study was relativism as there was a consideration that how people perceive the nature of reality cannot be the same for all (Wahyuni, 2012). The epistemological position taken was on subjective and contextual realities. Therefore, the study relied more on an interpretive paradigm because, according to Mack (2010), people interpret events differently, leaving multiple perspectives of an incident for the sake of understanding facts and explaining it.

\section{Study area and selection of participants}

Two community schools, one from an urban and the other from a rural area, were purposely chosen. The former was from the capital city of Nepal and the second was from 
Jumla, which is located in a remote place in the western mountainous district of Karnali province. The remote school was chosen because it has less access to central government officials. Regarding the number of participants, only two headteachers have been chosen as 'less is more' and can help generate meaningful information depending on the richness of the interview, research purpose, research question, and amount of data analyzed and interpreted (deMarais, 2004). The two headteachers comprised of a male with a master's degree, and a female $\mathrm{PhD}$ holder who was on the verge of retirement and had sound knowledge and experience about the research topic. Therefore, purposeful sampling was used since it is widely used in qualitative research to identify and select information-rich cases (Palinkas et al. 2015). With this technique, knowledgeable and experienced participants were identified and selected for the study purpose.

\section{Data collection}

In the process of exploring, the schools were visited time and again. To answer the research questions, one of the researchers became a good observer and a listener so that meaning-making could be done easily from the participants' stories, proverbs, metaphors, quotations, etc. The observation was a methodological omnivore with no single prescription for selecting an instrument for data collection (Cohen et al. 2013). The school head's behaviour and the school environment were observed because the school artifacts and headteachers' activities are highly affected by society and culture (Murchison, 2010). Therefore, data were collected using many ways such as field notes, interviews, observations, interpretations of artifacts, documents, and personal experiences (Denzin and Lincoln 2011).

To begin the interview, some open-ended questions based on the headteachers' code of conduct were asked by the first author. The interview was carried out during school hours or sometimes during public holidays. The first author visited the school in Jumla for 1 month and the school in Kathmandu for 4 months. Openended questions starting with "why?," "how?," and "what if?" were asked to get comprehensive answers.

\section{Data analysis}

The responses and data from the observation were analyzed qualitatively by developing codes. The codes were categorized and themes were obtained. The analysis showed that nepotism, unhealthy party politics and impunity were the three main root causes for integrity violation in Nepal and maintaining a proper balance between these triads was very difficult. Then all themes were discussed with literature.

\section{Credibility and ethical consideration}

The authors followed the strategies mentioned by Lincoln and Guba (1985), namely, thick description, prolonged engagement, persistent observation, and peer debriefing technique to ensure credibility. The meaning-making from the findings was done by verifying it through multiple sources, including literature, personal reflection, artifacts, observations, etc. It is because Lamont and Swidler (2014) argue for methodological pluralism and pragmatism for the rigour of a qualitative study. In this study, 
headteachers were interviewed; however, their opinions are cross-matched with the school supervisor. This is a way of assuring the validity of research so as to cross-validate information and capture a different dimension of the same category, theme or phenomenon. To maintain ethics, ethical guidelines- participant consent, rights to privacy, and protection from harm- (Denzin and Lincoln 2011) was followed. In a case where participants felt uncomfortable revealing the dark sides of integrity, it was given due consideration by respecting their privacy. Pseudonyms were used for the headteachers and the researchers acknowledged their participation after the completion of the task.

\section{Research findings}

The following section consists of a detailed description of themes obtained in the process of data analysis. The three themes of headteachers' integrity were distinct in the case principals of the study sites.

\section{Nepotism: is school an earning pot?}

During the data collection process, participants felt that teaching is not a socially esteemed profession in Nepal. It is a transitional job for many until they qualify as a civil servant or emigrate for a better opportunity. He also explained the malpractices in school. Avinash opined:

Our school is like our country, which is not poor but poorly managed. It has been made as a job recruitment place, even qualified are rejected if they do not go with the flow of power center. In Nepal, the notion ramra bhanda hamra manche (preferring our people than good people) works almost everywhere which is an extreme form of nepotism. For him, everything is okay if they get a chance to receive the fund and get their share; otherwise, school stakeholders' bargain about some confidential financial or moral matters.

On a similar note, the school supervisor shared that the commission that the headteachers get in stationery, furniture, teaching materials, uniform is common like any other business. Her colleagues prefer big institutional schools rather than community schools as they provide snacks, pocket money, gift, and a warm welcome for the same work. For her, nepotism, sin and ethics rotate around the power of moneyAn ideal headteacher hardly survives in an expensive city like Kathmandu, so they are engaged in real estate, share market for extra income and politics for a job promotion. It is because society is polarized according to status, power, and class that forces an individual to choose a profession accordingly. In this context, Bimala shared:

Now education is made as a business by the private sector as many nonacademic people polluted this charming profession which was rare in the autocratic Panchayat period. Sometimes schools perform religious rituals to raise funds from the public that can be misused in the name of quality education. In most cases, law binds the poor, not the elites' as our society measures success in terms of money, power and social rank, not integrity. 
Therefore, a principal needs to rethink professional integrity because society sees only the product of school, not the process of how it is achieved. This demonstration effect provides intense cut-throat competition between private and community schools, that is why integrity has been given a priority in Nepal. This was justified by Bimala's voice related to shooting and kidnapping during the election of School Management Committee (SMC) for school resources and appointing one's own people as school head.

\section{Impunity: where are rewards and punishments?}

During data analysis, impunity emerged as a major theme. This was relevant since the school supervisor mentions that he was offered a feast for his favour in providing scholarship to a headteacher's housemaid, school dress, and purchase of materials for the sake of commission. During an interview, Bimala said that these are very common issues in a country like Nepal because everybody wants to help their blood relatives, kith and kins rather than a stranger. There is a tendency of not supporting as well. She continued her story that once a male headteacher intentionally created an unfavorable situation as he scheduled all meetings in the evening. She faced difficulties attending the meeting since she had other responsibilities at home after school. Finally, she resigned from the position. For her, female teachers had to deal with cleaning room; kitchen work, and paperwork besides teaching as male teachers motivate them by saying a good housewife can handle a school more successfully.

There were cases of nepotism and internal party politics to favour one's own people. Headteachers had their duty to satisfy the SMC head, engineers, auditor, but also the political cadre for extortion money during the insurgency period. These are the ways to remain safe from the educational strike, job and life. For the legitimacy of such remark, Avinash related the story of his colleagues who have an inferiority complex with the assistant headteacher. He said that in the name of retrofitting after the earthquake, corruption began to appear when he demolished lab, restroom, and library. For that, he used Chanakya policy i.e. Saam (to advice and ask), Daam (to offer and buy), Dand (to punish) and Bhed (to exploit the secrets). For him, everything air, water, soil, sand particles were polluted by corruption during the construction of infrastructure. The situation after the earthquake was pathetic since fake photographs of the neighboring school's lab and toilet were reported to have been submitted to receive the fund.

While integrity violation and political influence are already an issue in school, many schools take financial and social audit as a burden and limit it only as a ritual to be performed without seriousness. The laws are interpreted differently for elite and poor people based on political faith, caste, and socioeconomic status. Politicians always used this commitment just as a tool to brainwash the public. If impunity is not ended, nepotism continues as the whole system is guided by an external super system of political and cultural domain. Therefore, there is a maximum probability for a wrong doer, who is close to SMC, and headteacher, to be rewarded.

\section{Party politics in education: an obligation or interest?}

Many teachers try to stay away from politics, but unfortunately, they get trapped in it when decisions are politically motivated. Now, many public schools are a hub for only poor parents. In this context, Avinash said that if bureaucrat, ambassador, artist, 
industrialist, student, etc. enter politics, why can't teachers reach to the policy implementation level. He added, today's president and ministers of the country are the outcome of public schools, and many leaders were teachers before they joined politics.

He tried to convince the first author that politics simply is not a matter of aligning with democratic and communist parties or whatsoever but it affects the school system. There was a case of school supervisor's bitter experience where a teacher was not appointed by the selection committee. It was because of political interest and favoritism towards their people, locals get a chance first rather than outsiders. In this connection, Bimala said that a school got some funds from the President's office as the head teacher of the school shared a similar political faith. However, later the budget was misused by painting old furniture and computers and faking them as new ones. Similarly, the school supervisor shared her experience that once a teacher, the wife of a local politician, remained absent in the name of deputation. She was a resident of the city area and she did not prefer to work in the countryside where her job was posted. She went to the village areas just for making their work profile look better for the sake of promotion rather than their passion and professional zeal. The supervisor added that she had to switch off her cell phone to avoid pressure from politicians and bureaucrats in deciding on the teachers' appointment and transfer to the urban area. She also shared a bitter experience about her brother who, unfortunately, got victimized by the headteacher since the latter scored him less during the promotion process. Even when two school headteachers receive an equal mark, the head-teacher with the political connection was considered the best for school award. Avinash also had a similar experience. He claims that even the government's discrimination of the teacher unions affiliated to ruling and opposition parties sets bad precedence in teachers' integrity. The experiences shared by the school supervisor regarding the head-teachers came as a shocking revelation. The multitasking job refers to both academic and administrative tasks that the head-teacher needs to perform is like 'jack of all trades, master of none'. All the above incidents conclude that corruption is the major problem; therefore, these triads are a double-edged sword and to maintain check and balance between them is a herculean task.

\section{Discussion}

According to Bista (1991), qualification, training, experiences are not so important if one's people are there because whenever a need arises work can be done through sycophancy. Groot (2007) mentions that despite having free education theoretically, students are supposed to pay for admission, stationery and uniform; hence it is unapproachable for impoverished families. The study by Sroka and Vveinhardt (2020) also confirms that nepotism and favouritsm have influenced negatively on that particular country's economy. National Education Commission 1992 also mentioned reward and punishment system for teachers is a must; otherwise, they enjoy the benefits of rare monitoring, which is the breeding ground for impunity.

This report blames the Panchayat polity for turning the educational sector into a political arena, so education today faces many problems. Our society creates political parties to achieve multiple sources of power that affect the market economy which is the essence of Weber's 3Ps (property, prestige and power) concept (Duran, 2009). Similarly, Kumar (2015) found that neoliberalism as promoted by the IMF, World Bank and WTO, has created domination and social violence. The Nepalese Education Act of 
1981 also provisioned SMC to prevent pollution of the school environment in the name of unhealthy party politics. Also, O'Neill et al.'s (2020) study shows the engagement of Nepali youth in universities as a political student union that reflects and refracts their political hunger and thirst.

Bhattarai (2015) also talks about excessive misuse of political power in our context, which has spoiled the quality of education and led to impunity. Despite having several efforts of human rights defenders, lawyers, journalists, and activists, there is a justice vacuum. Regarding female teachers, Bista (2006) found that patriarchy has enhanced gender discrimination, instilled negative attitudes in the male teachers about reproductive health, which, on the contrary, has caused stress, loneliness and discouragement in female teachers. The big question arises here is, who is responsible for such discrimination in school. Regarding negligence of community schools, Mathema (2007) reports that courses were not completed in time due to teachers' absenteeism, and even if they were present, they did not teach even when the resources were available.

In this context, House (2013) mentioned impunity is an ancient problem in Nepal and a great obstacle to justice, especially for the poor, women and marginalized groups who are devoid of education. Mathema (2007) found that institutional schools in Nepal spend eleven times more than public schools. The government policy of private-public partnership for positive discrimination and providing little budget will hardly improve the standard of education. In the same way, Bhattarai (2015) argues that due to the powerful interference of union politics, both principal and state are found to be helpless and meaningless inside the school. Teachers' unions are well-wishers of a political party, so they are more accountable towards politicians rather than schools. Sharing a similar geopolitical landscape and socio-cultural context, Nepal also has a similar situation to tackle unhealthy politics like that of India (Narayan 2014). This is also justified by Shrestha (2008) that teachers' active participation in politics is one of the reasons for the threat of school.

The quantitative study carried out in forty-three schools in seven US states found that teacher leadership differs by the experience, degree, and position they hold (Angelle and DeHart 2011). There is a much visible difference in the decision-making process of a male and a female principal primarily due to their sociocultural construct. For instance, women decide after they make several rounds of consultation, whereas men hardly do so (Bhattarai and Maharjan 2016). It must be noted that teaching is the mother of all other professions, and incidents of integrity violation made by the school head cannot be easily forgotten or ignored.

The study conducted by Manley-Casimir and Piddocke (1991) identified teacher relationships with the students, parents, colleagues, admin, head-teacher, community, teaching profession, state, teacher union, etc. The primary role of the teachers' union is to advocate proactively for the rights of the teachers and follow country curricula and policy. As per Azer (2005), the qualities such as committed, diversity caretaker, motivator, communicator, leadership, ethics, pedagogy, creativity, teamwork, political awareness, etc., of a good teacher can be either inherited or acquired. The young, energetic teachers have good academic exposure and are creative, committed, etc. These teachers have hardly any interest in politics; however, for old and experienced teachers, politics becomes obligatory as it serves as a tool to secure their job. This is primarily because the youth have several alternative options such as going abroad, finding a government 
job, or starting their own business, but such opportunities are less and limited for old teachers who are on the verge of retirement.

The overall scenario presented above can be viewed from the Organizational Culture Theory. This theory describes organizational culture as a system of shared beliefs that govern people's behaviour and job performance. The essence of this theory can be understood only by those who fall in its circumference. For instance, if the headteacher greets the staff, speaks in the assembly, shows friendly behaviour, it becomes the culture in the long run as he continues to practise and set an example alongside. It is the case of creating a healthy atmosphere that helps connect with people. However, such a technique is lacking in many community schools. On a similar note, Ravasi and Schultz (2006) describe organizational culture as a set of shared assumptions that guide behaviours and affect how people interact with each other and with concerned stakeholders. It is both a useful metaphor and an integrated concept for studying the school's environment that provides it with a particular climate while working.

For Needle (2010), organizational culture is the product of history, market, technology, policy, management style, and national culture. It is assumed that school heads remain fully updated about it and practice it daily. Similarly, Tischler (2013) mentions that both material and non-material culture help to shape a society structured by the family, religion, government, education, economy, and both national and international politics. In this regard, the head teacher's daily academic and administrative tasks are affected by the above-mentioned dimensions. For Northouse (2018), culture is the learned beliefs and traditions that are common to a group of people. In the context of a school as an organization, its culture influences the behaviour of people.

\section{Closing thoughts}

The nepotism, impunity, and party politics can be referred to as an integrity triad. In Nepal, they were given due consideration after the government drafted 'national integrity and zero-tolerance policies towards corruption' to address the worse scenario of educational malpractices. However, with the neo-liberal economy, person's greed of the head teachers for power, propery and prestige prevails. This caused the paradigm shift in the integrity triad, justifying it to be a double-edged sword. In the situation, the school stakeholders are playing the blame game by pointing at each other for the failure of integrity in school rather than reflecting upon their actions and finding a solution to such issue.

Political affiliation matters and influences the decisions to increase the school budgets, set agendas, create job stability, allocate quota, and admit a student. Schools are not mingled with politics to get benefits from it. Consequently, nepotism, impunity, and party politics have created biases in decision-making, led to unfair treatment, and deteriorated school performances in the long term. The violation of this triad makes people unethical, demotivated, and isolated. It also hinders confidence, healthy competition, and innovation. It is time that policy-makers think about the triad in their aim of reforming school education in Nepal. 


\section{Acknowledgements}

The authors would like to acknowledge an anonymous group of experts and participants, who provided support in this work.

\section{Authors' contributions}

BK engaged in the field, analyzed the data and was primarily responsible for writing the manuscript. PCB involved in conceptualizing the study, guiding the entire research process and finalizing manuscript. Both authors read and approved the final manuscript.

\section{Authors' information}

About Authors

Bhanu Khadka

Mr. Khadka pursued MPhil in Educational Leadership from Kathmandu University- School of Education and he is currently working as Faculty at Little Angels' College, Hattiban.

Prakash C Bhattarai

Prakash C Bhattarai, Ph.D. is an Associate Professor and Head at the Department of Development Education in

Kathmandu University-School of Education, Nepal. He teaches research, development theories, project evaluation, and carries out researches in the diverse areas of education and social sciences. He has been working as the faculty, project evaluator, researcher, and trainer in several international and national organizations. Some of his many experiences in the field of writing emanate from his diverse experiences. He has a keen interest in ethics, ethical leadership, integrity, anti-corruption, development, and vocational education.

\section{Funding}

The authors have not got financial support for the research, authorship, and/or publication of this article

\section{Availability of data and materials}

Due to confidentiality concerns, data generated by this study is only available by reasonable request to the corresponding author.

\section{Declaration}

\section{Competing interests}

The authors declare that they have no conflict of interest.

\section{Author details}

${ }^{1}$ Kathmandu University- School of Education, Hattiban, Lalitpur, Nepal. ${ }^{2}$ Department of Development Education, Kathmandu University-School of Education, Lalitpur, Nepal.

Received: 16 March 2021 Accepted: 16 October 2021

Published online: 20 December 2021

\section{References}

Amshah EFMA (2020) The challenges hindering the promotion of a culture of integrity at Jordanian Universities. J Educ Pract 11(16):134-147

Angelle PS, DeHart CA (2011) Teacher perceptions of teacher leadership: Examining, differences by experience, degree, and position. NASSP Bull 95(2):141-160

Azer SA (2005) The qualities of a good teacher: how can they be acquired and sustained? J R Soc Med 98(2):67-69. https:// doi.org/10.1177/014107680509800211

Bhattarai PC (2015) The ethics of educational administrators: are they uniform or contextual. J Ethic Educ Leadership 2(4):117

Bhattarai PC, Maharjan J (2016) Ethical decision making among women education leaders: a case of Nepal. In: Racially and ethnically diverse women leading education: a worldview. Emerald Group Publishing Limited. https://doi.org/10.1108/S14 $79-366020 c 160000025013$

Biamba CN (2012) The role of principals in government secondary schools in Cameroon: demands, constraints and choices: a case study of eight secondary [unpublished doctoral dissertation]. Stockholm University, Cameroon

Bista, D. B. (1991). Fatalism and development: Nepal's struggle for modernization. Orient Blackswan

Bista MB (2006) Status of female teachers in Nepal. United Nations educational, scientific, and cultural organization

Bretag T (2016) Handbook of academic integrity. Springer. https://doi.org/10.1007/978-981-287-098-8

Chapfika B (2008). The role of integrity in higher education. International Journal for Educational Integrity, 4(1), 66-81. https:// doi.org/10.21913/JEl.v4i1.192.

Chapman DW, Lindner S (2016) Degrees of integrity: the threat of corruption in higher education. Stud High Educ 41(2):247268. https://doi.org/10.1080/03075079.2014.927854

Cohen L, Manion L, Morrison K (2013) Research methods in education. Routledge. https://doi.org/10.4324/9780203720967

Commission for Investigation of Abuse of Authority. (2015) Twenty fourth annual report

Denzin NK, Lincoln YS (2011) The sage handbook of qualitative research. Thousand Oaks, CA Sage

deMarrais K (2004) Qualitative interview studies: Learning through experience. In: DeMarrais K and Lapan SD (eds)

Foundations for research: Methods of inquiry in education and the social sciences. Mahwah, NJ: Lawrence Erlbaum Associates, 51-68.

Dunn CP (2009) Integrity matters. Intern J Leadership Stud 5(2):102-125

Duran P (2009.). Max Weber and the making of politicians: A sociology of political responsibility. Max Weber Studies, 9(1-2): 51-93. 
Ertas N (2020) Administrative corruption and integrity violations in the charter school sector. Public Integrity 1-18(23):1. https://doi.org/10.1080/10999922.2020.1758535

Groot A (2007). Deprived children and education: Nepal. IREWOC, Amsterdam

House PB (2013) Nepal: the search for justice. Amnesty International

Kumar R (2015) Neoliberalism, critical pedagogy and education. Routledge. https://doi.org/10.4324/9781315659817

Lamont M, Swidler A (2014). Methodological pluralism and the possibilities and limits of interviewing. Qualitative Sociology, $37(2), 153-171$.

Le Billon, P. (2003). Buying peace or fuelling war: the role of corruption in armed conflicts. Journal of International Development, 15(4), 413-426. https://doi.org/10.1002/jid.993.

Lincoln YS, Guba EG (1985). Naturalistic inquiry. Newbury Park, CA: Sage.

Louis KS, Khalifa M (2018) Understanding and improving urban secondary schools: the role of individual and collective agency. J Educ Adm 56(5):446-454. https://doi.org/10.1108/JEA-08-2018-174

Mack L (2010). The philosophical underpinnings of educational research.Polyglossia,19, 1-11.

Manley-Casimir ME, Piddocke S (1991) Teachers in a goldfish bowl: a case of misconduct. Educ Law J 3(2):18-21

Mathema KB (2007) Crisis in education and future challenges for Nepal. Eur Bull Himalayan Res 31:46-66

Mathema KB, Bista MB (2006) Study on student performance in SLC. Ministry of Education and Sports

Ministry of Education \& Teachers Union of Nepal. (2007). Report on stakeholders' conferences on education development

Ministry of Education [MoE]. (2009). School sector reform plan, 2009-2015. Kathmandu: Author

Mlecko JD (1982) The guru in Hindu tradition. Numen 29(1):33-61. https://doi.org/10.1163/156852782X00132

Murchison J (2010). Ethnography essentials: Designing, conducting, and presenting your research (Vol. 25). Wiley.

Narayan L (2014) Corruption in education: nature and causes. Int J Res 1(8):211-223

Nas TF, Price AC, Weber CT (1986) The American Political Science Review, 80(1),107-119. http://www.jstor.org/stable/1957086.

National Planning Commission. (2015). Sustainable development goals 2016-2030. National (preliminary) report

National Vigilance Center (2017) Sixteenth Annual report. Kathmandu: Author.

Needle D (2010). Business in context: An introduction to business and its environment. London, UK: Cengage Learning

Northouse PG (2018) Leadership: theory and practice. Sage

O'Neill T, Poudel BR, Maharjan N (2020) Youth political engagement and democratic culture in republican Nepal. HIMALAYA, J Assoc Nepal Himalayan Stud 39(2):6

Osipian AL (2020) Nepotism in American universities starts resembling Ukraine. In: Corruption in higher education, pp 65-69 Brill sense

Palanski ME, Yammarino FJ (2007) Integrity and leadership: clearing the conceptual confusion. Eur Manag J 25(3):171-184 https://doi.org/10.1016/j.emj.2007.04.006

Palinkas LA, Horwitz SM, Green CA, Wisdom JP, Duan N, Hoagwood K (2015) Purposeful sampling for qualitative data collection and analysis in mixed method implementation research. Admin Pol Ment Health 42(5):533-544. https://doi. org/10.1007/s10488-013-0528-y

Ravasi D, Schultz M (2006). Responding to organizational identity threats: Exploring the role of organizational culture. Academy of management journal, 49(3), 433-458. https://doi.org/10.5465/amj.2006.21794663

Scotland J (2012). Exploring the philosophical underpinnings of research: Relating ontology and epistemology to the methodology and methods of the scientific, interpretive, and critical research paradigms. English Language Teaching, $5(9), 9-21$.

Shrestha K (2008) Teacher development and management at secondary education in Nepal. J Educ Res 1(1):41-51

Sroka W, Vveinhardt J (2020) Nepotism and favouritism: how harmful are these phenomena? Forum Scientiae Oeconomia 8(2):79-91

Stephens JM, Wangaard DB (2016) The achieving with integrity seminar: an integrative approach to promoting moral development in secondary school classrooms. Int J Educ Integr 12(1):1-16. https://doi.org/10.1007/s40979-016-0010-1

Sullivan B (1994) The religious authority of the Mahabharata: Vyasa and Brahma in the Hindu scriptural tradition. J Am Acad Relig 62(2):377-401. http://www.jstor.org/stable/1465271. https://doi.org/10.1093/jaarel/LXII.2.377

Tischler HL (2013). Introduction to sociology. London, UK: Cengage Learning.

Wagley MP, Regmi UR (2015) Crimes in education. The Kathmandu Post.

Wahyuni D (2012). The research design maze: Understanding paradigms, cases, methods and methodologies. Journal of Applied Management Accounting Research, 10(1), 69-80.

\section{Publisher's Note}

Springer Nature remains neutral with regard to jurisdictional claims in published maps and institutional affiliations.

Ready to submit your research? Choose BMC and benefit from:
- fast, convenient online submission
- thorough peer review by experienced researchers in your field
- rapid publication on acceptance
- support for research data, including large and complex data types
- gold Open Access which fosters wider collaboration and increased citations
- maximum visibility for your research: over 100M website views per year
At BMC, research is always in progress.
Learn more biomedcentral.com/submissions

